\title{
Modelling of pH, dry matter and mineral content of curds during soft cheese drainage
}

\author{
Daniel PICQUE ${ }^{a *}$, Ioan Cristian TRELEA ${ }^{\mathrm{a}}$, Yves GAUZERE ${ }^{\mathrm{b}}$, \\ Bernard MIETTON ${ }^{b}$, Georges CORRIEU ${ }^{\mathrm{a}}$ \\ a UMR Génie et Microbiologie des Procédés Alimentaires, INRA/INAPG, \\ 78850 Thiverval-Grignon, France \\ b ENILBIO, rue de Versailles, BP 49, 39801 Poligny, France
}

Received 29 September 2003 - Accepted 4 May 2004

Published online 4 August 2004

\begin{abstract}
The influence of the temperature at the rennet addition $\left(31.2,32.0\right.$ and $\left.32.8^{\circ} \mathrm{C}\right)$ and of the starter type on the soft cheese drainage process was studied. Off-line measurements of $\mathrm{pH}$, calcium and phosphorous concentrations, as well as dry matter of the curd were performed in parallel with on-line measurements of the weight and $\mathrm{pH}$ of the whey. Only the starter type was found to have a significant influence on the curd and whey $\mathrm{pH}$, on the calcium concentration in the curd and on the calcium/dry matter ratio. Correlations were established between weight of the whey and dry matter of the curd, as well as between $\mathrm{pH}$ of the whey and physico-chemical measurements in the curd. Linear regressions gave satisfactory results only when performed separately for each type of starter. Artificial neural networks allowed the building of common models for both starters and predicting curd $\mathrm{pH}$, calcium concentration and the calcium/dry matter ratio using the $\mathrm{pH}$ of the whey at one hour after moulding.
\end{abstract}

Drainage / curd characteristics / pH / starter / on-line measurement / modelling

Résumé - Modélisation du pH, de l'extrait sec et de la minéralisation du caillé pendant l'égouttage d'un fromage à pâte molle. Au cours de l'égouttage en moule de fromages à pâte molle, des mesures de $\mathrm{pH}$, de concentrations en calcium et phosphore ainsi que de l'extrait sec du caillé ont été effectuées parallèlement aux mesures en ligne de la masse et du $\mathrm{pH}$ du sérum. Les effets de la température d'emprésurage $\left(31,2 ; 32,0\right.$ et $\left.32,8^{\circ} \mathrm{C}\right)$ et de la nature des levains ont été évalués sur l'évolution de ces grandeurs. Seule la nature des levains présente un effet significatif sur les évolutions du $\mathrm{pH}$ du caillé et du sérum, sur la concentration en calcium du caillé et sur le rapport $\mathrm{Ca}^{++} /$extrait sec. Des corrélations sont établies entre la masse de sérum égoutté et l'extrait sec du caillé ainsi qu'entre le $\mathrm{pH}$ du sérum et les grandeurs physico-chimiques mesurées dans le caillé. Dans ces relations, les régressions linéaires multiples n'apportent des résultats corrects que lorsqu'elles sont établies séparément, en fonction du levain utilisé. La mise en œuvre de réseaux de neurones artificiels permet d'établir un modèle unique pour l'ensemble des variables recherchées.

Égouttage / caractéristiques physico-chimiques du caillé / pH / levain / mesure en ligne / modélisation

\footnotetext{
* Corresponding author: picque @ grignon.inra.fr
} 


\section{INTRODUCTION}

Drainage is a complex phenomenon resulting in whey elimination and hardening of the gel. It is an important stage of the cheese-making process, with a significant effect on the quality of the final product. Its evolution is influenced by various factors [9]: (i) physical factors such as cutting, mixing, heating, pressing and centrifugation [2] codified according to the type of required cheese; (ii) biological factors related to the milk composition; and (iii) biological agents such as lactic acid bacteria and rennet.

Walstra et al. [12] described the main cause of syneresis and reviewed the factors affecting the syneresis rate and end-point. The main factors are the distance over which the whey has to flow, pressure applied, temperature and pH. Kaytanli et al. [6] showed the effects of milk $\mathrm{pH}$, temperature, and calcium and rennet concentrations on the kinetics of draining. Recently, Daviau et al. [4] studied and modelled the effects of milk $\mathrm{pH}$, casein concentration and ionic strength of milks on the kinetics of soft cheese drainage.

Concurrently with the outflow of the whey, acidification occurs in the curd. The kinetic of acidification is modulated in practice by the choice of lactic acid bacteria, milk $\mathrm{pH}$ and temperature. Yun et al. [13] studied the impact of whey $\mathrm{pH}$ at draining (6.40/6.15) during Mozzarella cheese production. They showed that decreasing $\mathrm{pH}$ reduced calcium content in cheese, cheese moisture and the rate of proteolysis during storage. Kandarakis et al. [5] investigated the effects of draining temperature and starters on the biochemical characteristics of feta cheese. They found a significant effect of these parameters on $\mathrm{pH}$, total solids, nitrogen fractions and on organoleptic characteristics.

Real-time knowledge of curd $\mathrm{pH}$ and the ability to modify the kinetics of acidification acting on the temperature could allow control of draining and a better reproducibility of the process. But in practice, on-line measurement of curd $\mathrm{pH}$ during the drainage is not easy.
The goal of this work is to determine if it is possible to obtain the $\mathrm{pH}$ and some other important characteristics of the curd (dry matter, calcium and phosphorus contents) indirectly, using on-line measurements of $\mathrm{pH}$ and weight of the whey.

Draining experiments were carried out in order to quantify the variability of the process and of the on-line measurements, and to evaluate the effects of the milk temperature at the time of rennet addition and of lactic acid bacteria.

Linear and non-linear correlations were established between the measurements carried out on whey and those carried out on curd. Non-linear correlations were performed using artificial neural networks (ANN). Many successful applications of ANN are reported in the literature, especially in cases of complex phenomena when first-principle models are difficult to establish. For example, in the field of dairy production, Acuna et al. [1] used neural networks for estimating concentrations of lactic acid bacteria. Latrille et al. [7] used ANN for biomass, lactic acid concentration and $\mathrm{pH}$ estimation in yoghurt fermentation. Salehi et al. [10, 11] studied prediction of the milk yield based on neural networks.

\section{MATERIALS AND METHODS}

\subsection{Manufacture of soft cheeses}

Camembert cheese manufacture was carried out by the dairy technology laboratory of ENILBIO (Poligny, France). The milk was standardised for fat and protein content to $31.5 \mathrm{~g} \cdot \mathrm{L}^{-1}$ and $33 \mathrm{~g} \cdot \mathrm{L}^{-1}$, respectively. After heat treatment $\left(64^{\circ} \mathrm{C}\right.$ for $\left.20 \mathrm{~s}\right)$, $0.035 \mathrm{~g} \cdot \mathrm{L}^{-1}$ of anhydrous $\mathrm{CaCl}_{2}$ were added and $\mathrm{pH}$ was adjusted to 6.25 by addition of glucono- $\delta$-lactone. After $18 \mathrm{~h}$ at $10^{\circ} \mathrm{C}$, the milk was pasteurised for $20 \mathrm{~s}$ at $74^{\circ} \mathrm{C}$ and a new addition of $\mathrm{CaCl}_{2}$ identical to the first one was performed.

The milk $(75 \mathrm{~L})$ was poured into a $90-\mathrm{L}$ vat $(53 \mathrm{~cm} \times 53 \mathrm{~cm}$, hemispheric bottom). Either $10 \mathrm{~g} \cdot 100 \mathrm{~L}^{-1}$ of frozen mesophilic 
starter CHN11 (Chr. Hansen, Saint-Germainles-Arpajon, France) or $1 \mathrm{~g} \cdot 100 \mathrm{~g}^{-1}$ of "grand levain" Redi Set cultivated on skimmed milk (Chr. Hansen) were added. A surface flora (Rhodia Food, Dangé-Saint-Romain, France), involving Kluyveromyces lactis KL71 $\left(3 \times 10^{9}\right.$ cells $)+$ Geotrichum candidum GEO17 $\left(3 \times 10^{6}\right.$ spores $)$ and Penicillium camemberti VS $\left(3 \times 10^{9}\right.$ spores), was added to the milk. The milk was incubated for 30 min at either $31.2,32$ or $32.8^{\circ} \mathrm{C}$ depending on the experiment. Then, $20 \mathrm{~mL} \cdot 100 \mathrm{~L}^{-1}$ of rennet extract (Chr. Hansen) were added.

The total processing time was fixed to 5 times the coagulation time determined by the cheese-maker. The curd was cut out manually into 2 -cm-edge cubes and was stirred 20 min after the cutting. After $35 \mathrm{~min}, 30 \%$ of the whey was withdrawn and the curd was moulded into soft cheese moulds (internal diameter $105 \mathrm{~mm}$ ). The temperature of the room of the draining room was $28^{\circ} \mathrm{C}$ for $3 \mathrm{~h}$, decreased from $28^{\circ} \mathrm{C}$ to $20^{\circ} \mathrm{C}$ at a rate of $-1{ }^{\circ} \mathrm{C}$ per hour and remained at $20{ }^{\circ} \mathrm{C}$ during the night. The moulds were turned $1,3,6$ and $9 \mathrm{~h}$ after the moulding.

The experiments performed are listed in Table I. E1 to E4 and E5 to E8 were used to study the variability of the process and the effect of the temperature and of the starter, respectively.

\subsection{Analysis and measurements}

\subsubsection{Off-line analysis}

Determinations were carried out according to methods recommended by the International Dairy Federation for true protein (FIL98A-1985), phosphorus (FIL42B1990 in milk and whey, FIL 33C-1987 in curd) and for total dry matter (FIL21B1987 in milk and whey, FIL4A-1982 in curd). Calcium was measured by the method of Pearce described by Mutzelburg et al. [8], fat content by the Gerber method (AFNOR V04-210). Samples were taken at moulding, then after $1,2,3,4.5,6,9 \mathrm{~h}$ and at the end of the draining and were quickly cooled in a bath at $0{ }^{\circ} \mathrm{C}$.
Table I. Experimental conditions.

\begin{tabular}{lcc}
\hline Experiment code & Starter & $\begin{array}{c}\text { Temperature } \\
\text { at rennet addition } \\
{ }^{\circ} \mathrm{C}\left( \pm 0.1^{\circ} \mathrm{C}\right)\end{array}$ \\
\hline E1, E2, E3, E4 & CHN 11 & 32.0 \\
E5 & CHN 11 & 31.2 \\
E6 & Redi Set & 31.2 \\
E7 & CHN 11 & 32.8 \\
E8 & Redi Set & 32.8 \\
\hline
\end{tabular}

\subsubsection{On-line measurements}

The amount of whey which flowed out was weighed (Précisa 9670M, Paris, France, $12 \mathrm{~kg}$, accuracy $0.1 \mathrm{~g}$ ). Temperature (sensor Pt $100 \Omega$ at $0{ }^{\circ} \mathrm{C}$, Heito, Paris, France, accuracy $\pm 0.05^{\circ} \mathrm{C}$ ) and $\mathrm{pH}$ probes (pH BRV4 H TE, France, accuracy $\pm 0.02 \mathrm{pH}$ unit) were installed in a $10-\mathrm{mL}$ cell placed under the draining table. The same types of probes were placed into the curd. They had to be removed before each turning of the mould.

The transmitters of the sensors and the A/D converter modules were placed in a separate unit. The software, implemented on a PC, allowed the calibration of the sensors, the storage of the data provided by the interface, and its graphic representation.

\subsection{Data processing}

\subsubsection{Data acquisition}

Raw data were acquired every $2 \mathrm{~min}$. The processing consisted of retaining only one point every $10 \mathrm{~min}$, obtained as the average of the data points situated in a \pm 5 -min interval. Before taking the average, possible outliers were eliminated. Outliers were considered to be values situated beyond 1.5 times the inter-quartile distance away from the median. Confidence intervals were computed based on the Student probability distribution. For 4 measurements, that is, 4 repetitions of the experiment and hence 3 degrees of freedom, a $95 \%$ confidence interval is \pm 3.18 times the standard deviation. 


\subsubsection{Linear regression}

Linear regression models between online measurements (weight and $\mathrm{pH}$ of the whey) and target variables (curd pH, dry matter, calcium, phosphorous and the calcium/ dry matter ratio) were established using standard spreadsheet software (Excel, Microsoft, Redmond, USA).

\subsubsection{Non-linear models}

Non-linear models based on artificial neural networks were used when linear models did not give satisfactory results. Feed-forward artificial neural networks (ANN) are universal non-linear regression tools based on super-positions of sigmoid functions [3]. They assume no special form of the underlying relationship but are able to "learn" it from a set of examples (input-output couples), by adjusting their internal parameters. After the learning was completed, the "generalisation" ability of the network was tested on a set of previously unseen examples which formed the validation data set.

The general structure of the ANN used in this work is shown in Figure 1. The input variables were selected after a large number of tests, among the measurements performed in the whey at different moments in time: $\mathrm{pH}$, temperature, serum mass, and their combinations. The retained input variables were the whey $\mathrm{pH}$ at $1 \mathrm{~h}$ after moulding and the time. The whey $\mathrm{pH}$ at $1 \mathrm{~h}$ was selected because it produced accurate results and was available early enough to give useful predictions. The output variables were the curd $\mathrm{pH}$, the calcium concentration and the $\mathrm{Ca} / \mathrm{DM}$ ratio. The output variables are predicted at any given time as input, between 0 and $24 \mathrm{~h}$ (Fig. 1).

The learning set was formed of the data from experiments E1, E4, E5 and E8, and the validation data set of experiments $\mathrm{E} 2$, E3, E6 and E7.

\section{RESULTS}

\subsection{Curd-making mass balance}

From the 8 trials, mass balance was calculated from the different weights (milk,

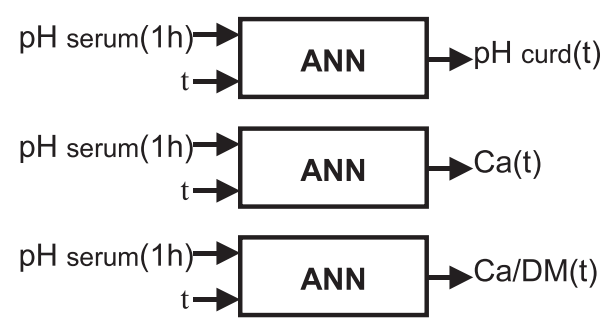

Figure 1. General structure of the artificial neural network models used.

whey and curd), and from their dry matter and fat composition. The recoveries were $94.83 \%(\mathrm{SD}=1.36$ ) for the total weight, $97.8 \%(\mathrm{SD}=1.52)$ for the dry matter and $99.64 \%$ for the fat $(\mathrm{SD}=4.54)$. The low value calculated for the weight was assigned to the losses by evaporation and to the handling during the process.

\subsection{Drainage description}

\subsubsection{Typical evolution and repeatability}

Repeatability of the drainage process was based on data from experiments E1 to E4 carried out under the same conditions (Tab. I). Figure 2 represents the changes versus drainage time of all data provided by on-line measurements and physico-chemical analysis.

Changes in the amounts of whey drained during the four experiments are represented in Figure 2A. The curves can be arbitrarily divided into three phases. During a first very short phase (about $15 \mathrm{~min}$ ), the amount of collected whey reached approximately $15 \mathrm{~kg}$, the whey coming mainly from draining in the vat. This phase has the greatest variability (coefficient of variation from 5 to $30 \%$ ) because of the transfer of the curd from the tank to the moulds. During the second phase $(6 \mathrm{~h})$, the quantity of whey increased to $96 \%$ of the total mass. In the third phase, between the 6 th and the 23 rd hour, only $4 \%$ of the total were collected. These changes are well 

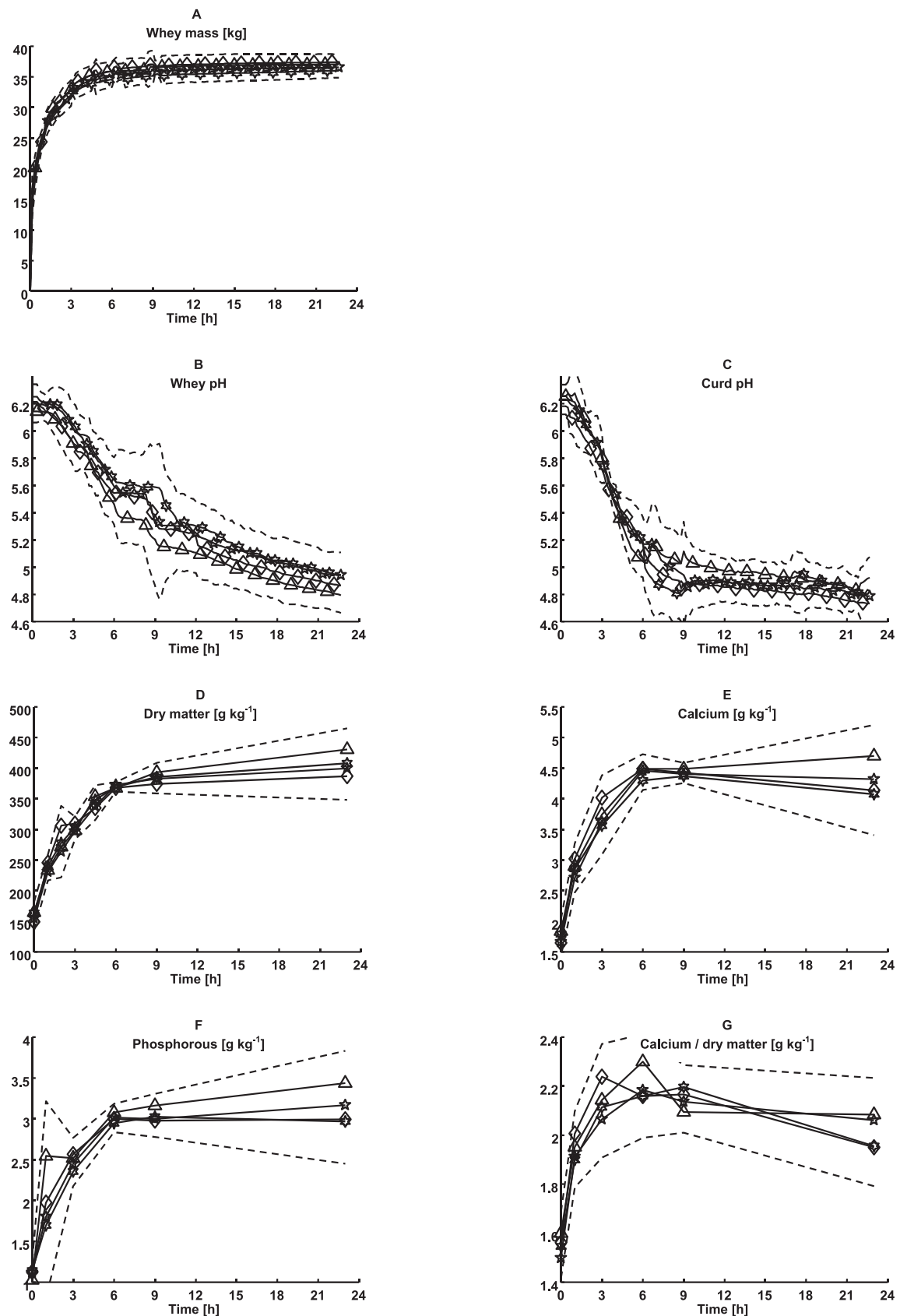

Figure 2. Repeatability experiments (E1: $\Delta, \mathrm{E} 2: \diamond, \mathrm{E} 3$ : 放, and E4: Weight (A) and $\mathrm{pH}$ (B) changes in whey. $\mathrm{pH}(\mathrm{C})$, dry matter (D), calcium concentration (E), phosphorous concentrations (F) and calcium/dry matter ratio (G) changes in curd. The dotted lines represent the $95 \%$ confidence interval. 
known and confirm previous works $[4,11]$. Depending on the experiment, a final quantity ranging between $36 \mathrm{~kg}$ and $37.4 \mathrm{~kg}$ of serum was collected, with an average of $36.8 \pm$ $1.9 \mathrm{~kg}$. Beyond $15 \mathrm{~min}$, the coefficients of variation calculated on the data of the 4 experiments acquired at the same moments are lower than $2 \%$, showing a good repeatability.

The changes in the $\mathrm{pH}$ of the whey and of the curd are represented in Figures 2B and $2 \mathrm{C}$. During the first $6 \mathrm{~h}$, the $\mathrm{pH}$ of the whey fell by about 0.65 unit. Beyond $6 \mathrm{~h}$, the measurement is no longer representative because of the flow rate of the serum in the measuring cell being too low. In the curd, the decrease was fast until the 9th hour and the $\mathrm{pH}$ reached 4.9: the total $\mathrm{pH}$ decrease from the beginning was 1.3 unit. During the next $14 \mathrm{~h}$, the decrease was only 0.14 unit. The confidence interval around the average value is about $\pm 0.2 \mathrm{pH}$ unit.

The changes in dry matter (DM), calcium (Ca) and phosphorus (P) and of the $\mathrm{Ca} / \mathrm{DM}$ ratio in the curd are shown in Figures 2D to $2 \mathrm{G}$. The concentrations increased during the first $9 \mathrm{~h}$, respectively, by a factor of 2.34 , $2.55,2.76$ and 1.39. Except for the phosphorus content after $6 \mathrm{~h}$ of draining, the coefficients of variation calculated for the four tests are lower than $6 \%$.

A measurement of the $\mathrm{pH}$ of the curd was also carried out off-line. Good correlation with the measurements carried out on line on the curd $\left(\mathrm{R}^{2}=0.98\right)$ was found (data not shown).

\subsubsection{Effects of the temperature and of the starter}

The values measured during the experiments at temperatures of 31.2 and $32.8^{\circ} \mathrm{C}$ in the presence of the starters CHN11 or Redi Set (experiments E5 to E8, Tab. I) are compared with the average and the confidence interval at $95 \%$ calculated during the repeatability tests (experiments E1 to E4). The results are presented in Figures 3A to 3G.

No effect of the considered operating conditions was observed on the changes in the amount of whey (Fig. 3A). The recorded values are included in the confidence interval of the repeatability tests. The kinetics have very similar profiles.

Concerning the $\mathrm{pH}$ decrease, the situation is different. A slight temperature effect can be seen in Figures 3B and 3C. It is hardly significant, however, since the values of $\mathrm{pH}$ of whey and curd measured in the experiments with the starter CHN11 at 31.2 and $32.8^{\circ} \mathrm{C}$ are included in the confidence interval calculated at $32{ }^{\circ} \mathrm{C}$ for the same starter for most of the time. On the contrary, a starter effect appears clearly (Figs. 3B, 3C). For the starter Redi Set, the $\mathrm{pH}$ of curd at moulding was lower, 6.1 compared with 6.2, and the decrease in the $\mathrm{pH}$ was faster. After $5 \mathrm{~h}$, the $\mathrm{pH}$ reached 5.25 in the serum and 4.8 in the curd, respectively, in comparison with 5.8 and 5.3 for the CHN 11 starter. At the end of the drainage, the $\mathrm{pH}$ in the curd obtained with Redi Set was lower by approximately 0.15 unit as compared with the starter CNH11.

The changes in dry matter and phosphorus in the curd are similar to those recorded during the tests of repeatability (Figs. 3D, $3 \mathrm{~F})$. Their values are included in the confidence interval.

For the tests carried out with the starter Redi Set, the concentrations of calcium measured after $6 \mathrm{~h}$ of drainage were lower than those using the starter CHN 11 (Fig. 3E). This difference is assigned to a faster acidification, leading to a more significant demineralisation of the curd. The calcium concentration changes especially when the $\mathrm{pH}$ decreases from 6.6 to 5.4. The $5.4 \mathrm{pH}$ value was reached after $2 \mathrm{~h} 30 \mathrm{~min}$ with the Redi Set starter and after $5 \mathrm{~h}$ with the CHN11 starter.

The calcium concentration is anomalous, however, because it is lower in experiments E5 and E7 than in E1 - E4 (except at $3 \mathrm{~h}$ ) even if the same starter was used. This difference can hardly be attributed to the different temperature but rather to a different milk composition used in experiments $E 5$ to E8. The $\mathrm{Ca} / \mathrm{DM}$ ratio (Fig. 3G) seems to be 

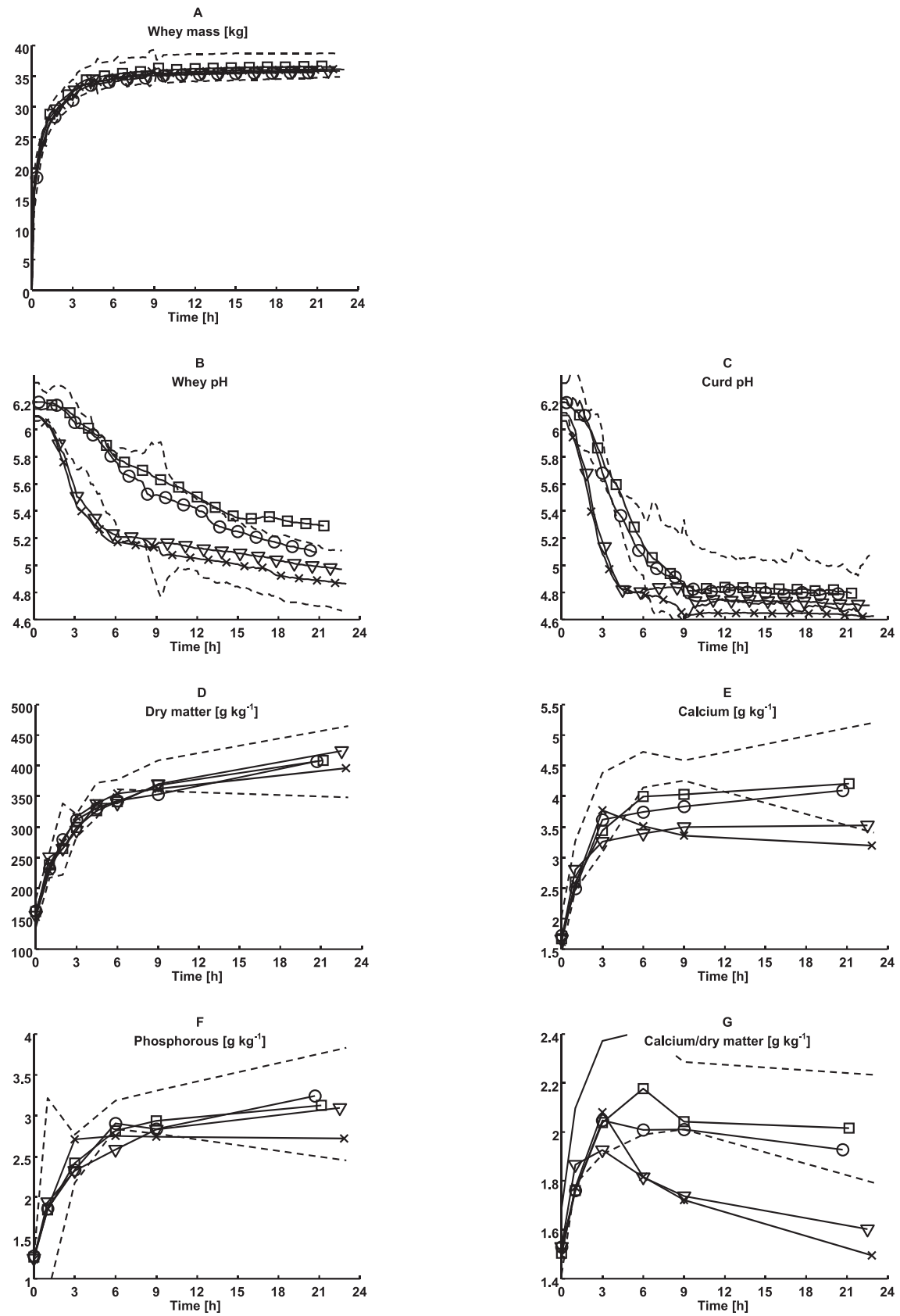

Figure 3. Effect of the temperature at rennet addition (experiments E5: $O$ and E7: $\square$ ) and of the starter type (experiments E6: $\times$ and E8: $\nabla$ ) on the evolution of weight (A) and $\mathrm{pH}(\mathrm{B})$ of the whey and the $\mathrm{pH}(\mathrm{C})$, dry matter $(\mathrm{D})$, calcium concentration $(\mathrm{E})$, phosphorous concentration $(\mathrm{F})$ and the calcium/dry matter ratio $(\mathrm{G})$ in the curd. The dotted lines represent the $95 \%$ confidence interval from the repeatability experiments E1 to E4. 
Table II. Multiple linear regressions between on-line measurements in the whey [weight (SM) and $\mathrm{pH}$ of the whey $(\mathrm{pH} \mathrm{W})]$ and the target variables measured in the curd (dry matter (DM), $\mathrm{pH}$ of the curd $(\mathrm{pH} \mathrm{C}$ ), calcium concentration $(\mathrm{Ca})$, phosphorous concentration $(\mathrm{P})$ and $\mathrm{Ca} / \mathrm{DM}$ ratio).

\begin{tabular}{|c|c|c|c|c|}
\hline Experiments & Relationship & $R^{2}$ & $\begin{array}{c}\text { Residual } \\
\text { standard } \\
\text { deviation }\end{array}$ & Range \\
\hline $\mathrm{E} 1-\mathrm{E} 8$ & $\mathrm{DM}=158+12.36 \mathrm{SM}-0.83 \mathrm{SM}^{2}+0.018 \mathrm{SM}^{3}$ & 0.96 & 15.50 & $150-450 \mathrm{~g} \cdot \mathrm{kg}^{-1}$ \\
\hline $\mathrm{E} 1-\mathrm{E} 8$ & $\mathrm{pH} \mathrm{C}=29.34-9.81 \mathrm{pH} \mathrm{W}+0.979 \mathrm{pH} \mathrm{W}^{2}$ & 0.89 & 0.18 & $4.5-6.5 \mathrm{pH} \mathrm{u}$. \\
\hline E1 - E5, E7 & $\mathrm{pH} \mathrm{C}=105-35.69 \mathrm{pH} \mathrm{W}+3.20 \mathrm{pH} \mathrm{W}^{2}$ & 0.96 & 0.08 & \\
\hline E6, E8 & $\mathrm{pH} \mathrm{C}=26.3-8.89 \mathrm{pH} \mathrm{W}+0.91 \mathrm{pH} \mathrm{W}^{2}$ & 0.99 & 0.04 & \\
\hline $\mathrm{E} 1-\mathrm{E} 8$ & $\mathrm{Ca}=-67.76+27.07 \mathrm{pH} \mathrm{W}-2.54 \mathrm{pH} \mathrm{W}^{2}$ & 0.68 & 0.53 & $1.5-4.5 \mathrm{~g} \cdot \mathrm{kg}^{-1}$ \\
\hline E1 - E5, E7 & $\mathrm{Ca}=-68.00+27.72 \mathrm{pH} \mathrm{W}-2.63 \mathrm{pH} \mathrm{W}^{2}$ & 0.85 & 0.38 & \\
\hline E6, E8 & $\mathrm{Ca}=-61.08+24.48 \mathrm{pH} \mathrm{W}-2.31 \mathrm{pH} \mathrm{W}^{2}$ & 0.82 & 0.31 & \\
\hline $\mathrm{E} 1-\mathrm{E} 8$ & $\mathrm{P}=-39.06+16.19 \mathrm{pH} \mathrm{W}-1.55 \mathrm{pH} \mathrm{W}^{2}$ & 0.79 & 0.32 & $1-3.5 \mathrm{~g} \cdot \mathrm{kg}^{-1}$ \\
\hline $\mathrm{E} 1-\mathrm{E} 5, \mathrm{E} 7$ & $\mathrm{P}=-43.92+18.07 \mathrm{pH} \mathrm{W}-1.73 \mathrm{pH} \mathrm{W}^{2}$ & 0.87 & 0.26 & \\
\hline E6, E8 & $\mathrm{P}=19.13+9.00 \mathrm{pH} \mathrm{W}-0.92 \mathrm{pH} \mathrm{W}^{2}$ & 0.87 & 0.22 & \\
\hline $\mathrm{E} 1-\mathrm{E} 8$ & $\mathrm{Ca} / \mathrm{DM}=-23.56+9.31 \mathrm{pH} \mathrm{W}-0.84 \mathrm{pH} \mathrm{W}^{2}$ & 0.41 & 0.18 & $1.5-2.2 \%$ \\
\hline $\mathrm{E} 1-\mathrm{E} 5, \mathrm{E} 7$ & $\mathrm{Ca} / \mathrm{DM}=-20.69+8.41 \mathrm{pH} \mathrm{W}-0.77 \mathrm{pH} \mathrm{W}^{2}$ & 0.62 & 0.14 & \\
\hline E6, E8 & $\mathrm{Ca} / \mathrm{DM}=-4.25+13.07 \mathrm{pH} \mathrm{W}-1.18 \mathrm{pH} \mathrm{W}^{2}$ & 0.78 & 0.09 & \\
\hline
\end{tabular}

a better mineralisation indicator than the $\mathrm{Ca}$ concentration alone. Experiments E5 and E7 appear to be similar to E1 to E4, while E6 and E8, using a different starter, are clearly different. The higher values are reached after $3 \mathrm{~h}$ with the Redi Set starter and after $6 \mathrm{~h}$ with the CHN11 starter. Beyond these times, the $\mathrm{Ca} / \mathrm{DM}$ ratio does not change for CHN11 but decreases for Redi Set.

In summary, the only observed effects were those of the starter on the changes in whey $\mathrm{pH}$ and in the $\mathrm{pH}$, calcium concentration and calcium/dry matter ratio of the curd.

\subsection{Estimation and prediction}

The purpose of this study was to be able to know in real time the $\mathrm{pH}$ and the dry matter of the curd, as well as the calcium and phosphorus concentrations and the $\mathrm{Ca} / \mathrm{DM}$ ratio. A more ambitious goal was to predict the evolution of these variables from a given moment to the end of the drainage process. Relationships between the on-line measurements (weight and $\mathrm{pH}$ of the whey) and the five mentioned variables (curd $\mathrm{pH}$, dry matter, calcium and phosphorous concentrations and the $\mathrm{Ca} / \mathrm{DM}$ ratio) were searched for. Two approaches were explored, the first one based on multiple linear regressions and the second one on artificial neural networks.

\subsubsection{Multiple linear regressions for real-time estimation}

For each of the five target variables, the linear regressions with the significant factors (at a 0.05 level) are summarised in Table II. The temperature was never retained as a significant factor.

The correlation between the amount of whey and the dry matter of the curd has a high determination coefficient. The residual standard deviation is $15.5 \mathrm{~g} \cdot \mathrm{kg}^{-1}$.

The estimation of the curd $\mathrm{pH}$, calcium and phosphorus concentrations and $\mathrm{Ca} / \mathrm{DM}$ 
Table III. Prediction errors for the $\mathrm{pH}$, calcium concentration and the calcium/dry matter ratio of the curd using $\mathrm{pH}$ measurements in the whey and artificial neural network models.

\begin{tabular}{lccccc}
\hline $\begin{array}{l}\text { Predicted variable } \\
\text { in curd }\end{array}$ & \multicolumn{2}{c}{$\begin{array}{c}\text { Prediction accuracy } \\
\text { Residual standard deviation }\end{array}$} & $\begin{array}{c}\text { Repeatability } \\
\text { of the experiments } \\
\text { standard deviation }\end{array}$ & $\begin{array}{c}\text { Analytical } \\
\text { accuracy }\end{array}$ & Units \\
\hline & $\begin{array}{c}\text { Test database } \\
\text { E1, E4, E5, E8 }\end{array}$ & $\begin{array}{c}\text { Learning database } \\
\text { E2, E3, E6, E7 }\end{array}$ & E1 - E4 & & \\
$\mathrm{pH}$ & 0.05 & 0.03 & 0.04 & 0.03 & $\mathrm{pH} \mathrm{u}$ \\
Calcium & 0.35 & 0.32 & 0.16 & 0.28 & $\mathrm{~g} \cdot \mathrm{kg}^{-1}$ \\
$\begin{array}{l}\text { Calcium/dry } \\
\text { matter }\end{array}$ & 0.10 & 0.06 & 0.06 & 0.07 & $\mathrm{~g} \cdot \mathrm{kg}^{-1}$ \\
\hline
\end{tabular}

ratio based on the whey $\mathrm{pH}$ by a single relationship for the whole pool of experiments was not satisfactory (determination coefficients between 0.41 and 0.89 ). Separating the experiments between the CHN 11 (E1 to E5 and E7) and Redi Set (E6 and E8) starters improved the results significantly. The prediction accuracy of the $\mathrm{pH}$ in the curd was lower than 0.1 unit, which is satisfactory. For calcium and phosphorus, the reduction in the residual standard deviation was about $30 \%$ when using separate regressions. The residual standard deviation for the $\mathrm{Ca} / \mathrm{DM}$ ratio decreased between 20 and $50 \%$.

\subsubsection{Artificial neural networks for prediction}

The artificial neural networks shown in Figure 1 were used to predict the $\mathrm{pH}$, the calcium concentration and the $\mathrm{Ca} / \mathrm{DM}$ ratio in the curd, based on the $\mathrm{pH}$ measured in the whey at $1 \mathrm{~h}$ after moulding. The type of starter is not entered explicitly, but is accounted for by the value of $\mathrm{pH}$ in the serum at $1 \mathrm{~h}$, which is significantly different for the two starters.

For the $\mathrm{pH}$ and the $\mathrm{Ca} / \mathrm{DM}$ ratio of the curd, the prediction error of the ANN models was close to the repeatability of the experiments (Tab. III). For the calcium concentration, the prediction error was significantly higher than the repeatability. This was due to the fact that the calcium concentration was globally higher in the whole pool of experiments E1 - E4 than in the pool E5 $\mathrm{E} 8$, as shown in Figure 3E, while no measured variable in the whey could account for this difference. Figure 4 indicates that the
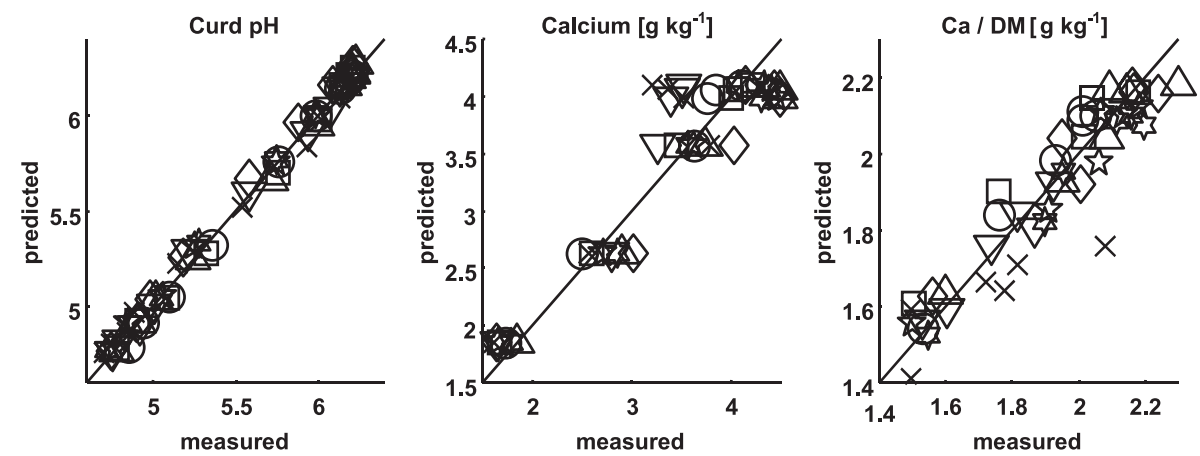

Figure 4. Accuracy of the artificial neural network models. Predicted versus measured values. Experiments E1: $\Delta$, E2: $\diamond, \mathrm{E} 3:$ 光, E4: E5: O, E6: $\times, \mathrm{E} 7: \square$ and E8: $\nabla$. 
prediction accuracy was similar in the entire ranges of the predicted variables, with the exception of the highest calcium concentrations, which were predicted less accurately. Models for the dry extract and for the phosphorus concentration were also tried but were found to perform nothing more than time interpolation between existing data points. This was expected since the experiments were not significantly different.

From a practical point of view, the models can be used with data from a manual $\mathrm{pH}$ meter, since a single $\mathrm{pH}$ value is needed. Thus, a pH measurement cell is not required.

\section{CONCLUSIONS}

To study the drainage phenomenon in soft cheese-making, eight experiments were performed, combining three temperature levels (rennet temperature addition) and two starters. The only observed effects were those of the starters on the changes in whey $\mathrm{pH}$, and in the $\mathrm{pH}$, calcium concentration and calcium/dry matter ratio of the curd.

It was shown that the dry extract of the curd can be estimated from the mass of the drained serum using multiple linear regressions. The $\mathrm{pH}$ of the whey can be used either to estimate or to predict the $\mathrm{pH}$ of the curd and its calcium content, as well as the calcium/ dry matter ratio. In all cases, the estimation and prediction accuracy was close to the repeatability of the experiments.

Similar tools could be developed for other cheese-making processes. The most appropriate measurements to perform in the serum and the model coefficients should be determined separately for each type of process, however.

Acknowledgements: This research was partially supported by ARILAIT. The authors would like to thank the ARILAIT sensor committee for its scientific assistance.

\section{REFERENCES}

[1] Acuna G., Latrille E., Beal C., Corrieu G., Static and dynamic neural network models for estimating biomass concentration during thermophilic lactic acid bacteria batch cultures, J. Ferment. Bioeng. 85 (1998) 615-622.

[2] Akkerman J.C., Buijsse C.A.P., Schenk J., Walstra P., Drainage of curd: role of drainage equipment in relation to curd properties, Neth. Milk Dairy J. 50 (1996) 371-406.

[3] Bishop C.M., Neural networks and their applications, Rev. Sci. Instrum. 65 (1994) 1803-1832.

[4] Daviau C., Pierre A., Famelart M.H., Goudédranche H., Jacob D., Garnier M., Maubois J.L., Characterisation of whey drainage kinetics during soft cheese manufacture in relation with the physicochemical and technological factors, $\mathrm{pH}$ at renneting, casein concentration and ionic strength of milk, Lait 80 (2000) 417-432.

[5] Kandarakis I., Moatsou A.I.K., Georgala S., Kaminarides S., Anifantakis E., Effect of draining temperature on the biochemical characteristics of Feta cheese, Food Chem. 72 (2001) 369-378.

[6] Kaytanli M., Erdem Y.K., Tamae I.M., Factors affecting whey drainage of renneted skim milk gels: a kinetic approach, Milchwissenschaft 49 (1994) 197-200.

[7] Latrille E., Corrieu G., Thibault J., pH prediction and final fermentation time determination in lactic acid batch fermentations, Comput. Chem. Eng. 17 (1993) 423-428.

[8] Mutzelburg I.D., Law M.A., Durward I.G., Adaptation and evaluation of rapid methods for the determination of calcium in milk, Aust. J. Dairy Technol. 34 (1979) 114-117.

[9] Ramet J.P., L'égouttage du coagulum, in: Eck A. (Ed.), Le Fromage, Tec \& Doc Lavoisier, Paris, 1997, pp. 42-61.

[10] Salehi F., Lacroix R., Wade K.M., Improving dairy yield predictions through combined record classifiers and specialized artificial neural networks, Comput. Electron. Agric. 20 (1998) 199-213.

[11] Salehi F., Lacroix R., Wade K.M., Development of neuro-fuzzifiers for qualitative analyses of milk yield, Comput. Electron. Agric. 28 (2000) 171-186.

[12] Walstra P., van Dijk H.J.M., Geurts T.J., The syneresis of curd. 1. General considerations and literature review, Neth. Milk Dairy J. 39 (1985) 209-246.

[13] Yun J.J., Barbano D.M., Kindstedt P.S., Larose K.L., Mozarella cheese, impact of whey $\mathrm{pH}$ at draining on the chemical composition, proteolysis, and functional properties, J. Dairy Sci. 78 (1995) 1-7. 